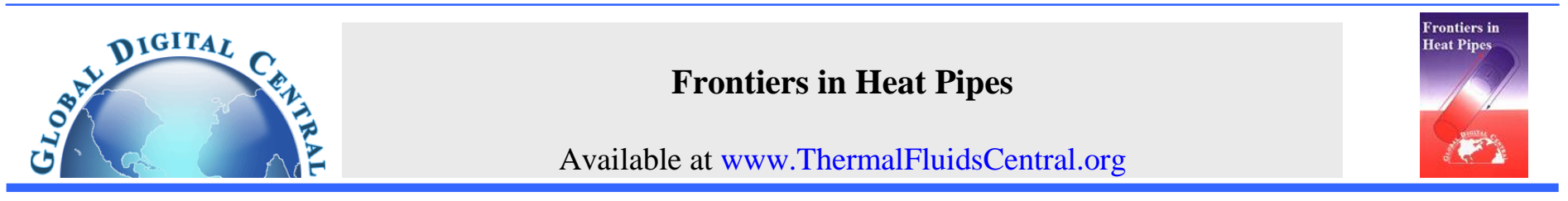

\title{
PERFORMANCE OF WATER FILLED THERMOSYPHONS BETWEEN $30-150^{\circ} \mathrm{C}$
}

\author{
K. S. Ong* and Christopher Lim \\ Department of Industrial Engineering, Universiti Tunku Abdul Rahman, 31900 Kampar, Perak, Malaysia.
}

\begin{abstract}
The thermal performances of three water-filled thermosyphons subjected to evaporator wall temperatures between $30-150^{\circ} \mathrm{C}$ were investigated. The effect of condenser cooling rates together with various fill ratios from $0.25-1.00$, thermosyphon inclination angles from $23^{\circ}-90^{\circ}$ and aspect ratios from 5.0-10.0 were investigated. Power inputs from 5-405 W resulted in evaporator wall temperatures up to $185^{\circ} \mathrm{C}$. Water coolant flow rates from $0.003-0.05 \mathrm{~kg} / \mathrm{s}$ were employed. Axial temperature distribution was found to be uniform at power input $<18 \mathrm{~W}$ and non-uniform at high power input. Evaporator wall temperatures based on bulk and mean values show differences of at least $14^{\circ} \mathrm{C}$ at the high power values. The performance of the thermosyphons based on heat transferred varied linearly with mean or bulk temperature difference and was dependent upon fill ratio and inclination. The best performing thermosyphon was found to be at a fill ratio of 1.00 in the vertical position. Also, a high length/diameter aspect ratio thermosyphon performed better than one with a low aspect ratio.
\end{abstract}

Keywords: Thermosyphon, condenser cooling rates, high power input, inclination, fill ratio, aspect ratio.

\section{INTRODUCTION.}

Heat pipes (HPs) are very effective heat transfer devices capable of transferring large amounts of heat effectively and efficiently. Peterson (1994) mentions that a HP typically consists of a sealed container lined with a wicking material. The container is evacuated and filled with just enough liquid to fully saturate the wick. A wickless HP, known as a thermosyphon is shown in Fig. 1. Heat applied at the evaporator section causes the liquid to boil and vaporize, picking up latent heat of vaporization. Vapor rises to the condenser section where it condenses and gives up its latent heat of condensation. The condensate then travels back to the evaporator section by gravity. The performance of a thermosyphon is dependent on the fill ratio (FR), types of fill liquid, power input at the evaporator $(\mathrm{P})$, heat removed from the condenser, inclination $(\theta)$ and length/diameter aspect ratio (AR). An optimal FR is important as too much fill liquid can cause flooding and too little will cause dry out. Both these phenomena are undesirable as they reduce the performance of the heat pipe. Flooding occurs when liquid collecting in the condenser and adiabatic regions are unable to return to the evaporator section. Dry out occurs when the rate of return of the condensate from the condenser section is insufficient to meet the evaporation rate due to high heat flux in the evaporator section. The operating heat flux applied to the evaporator section is important as well. A high heat flux can induce violent boiling in the evaporator section causing blockage of condensate. Prolong exposure to high heat flux can also induce dry out. There is an optimum pipe diameter related to a vapour flow such that any increase in the pipe diameter may contribute to the flooding phenomenon. An increased pipe diameter is desirable to avoid flooding. Axial heat conduction occurs along the pipe wall. The magnitude of this heat transfer compared to the heat transfer by evaporation and condensation in a thermosyphon would be comparable if the heat input is small. Generally, a temperature difference between evaporator and condenser section of about $5^{\circ} \mathrm{C}$ is required to initiate operation of the thermosyphon. This would depend upon the type of fill liquid and the physical dimensions of the pipe.

Nguyen-Chi and Groll (1981) investigated the entrainment or flooding limit in a closed two-phase thermosyphon with a water filled $20 \mathrm{~mm}$ OD x $17 \mathrm{~mm} \mathrm{I/D} \mathrm{x} 2.5 \mathrm{~m}$ long copper thermosyphon with inner circumferential grooves. Evaporator and condenser sections were each $1.0 \mathrm{~m}$ long. The evaporator section was heated with electrical resistance wires and the condenser cooled via a water cooling jacket. FR was between $0.38-0.88$, inclination angle from $1-80^{\circ}$, evaporator wall temperature from $20-80^{\circ} \mathrm{C}$ and power input between $100-420 \mathrm{~W}$. They derived an empirical correlation to predict the maximum performance for the inclined thermosyphon and recommended further work to be performed to determine the influence of parameters like FR, aspect ratio, internal surface roughness of pipe and type of working fluid.

Gurses and Cannistraro (1991) studied the inclination effect on water filled heat pipes for solar energy applications with an $18 \mathrm{~mm}$ OD x $15 \mathrm{~mm} \mathrm{I/D} \mathrm{x} 1.93 \mathrm{~m}$ long copper pipe. The air-cooled condenser was $420 \mathrm{~mm}$ long fitted with external $400 \mathrm{~mm}$ diameter fins. Power input of up to $1200 \mathrm{~W}$ resulted in a evaporator wall temperature range of up to $70^{\circ} \mathrm{C}$. They concluded that the best inclination angles are between $45-$ $90^{\circ}$ due to entrainment limit and capillary limit, and is dependent on the power input range. Terdtoon et. al. (1996) investigated the effect of aspect ratio and Bond number on the heat transfer characteristics of a two-phased closed loop thermosyphon. They used copper pipes with 7.5, 11.1 and $25.9 \mathrm{~mm}$ diameter with corresponding AR values of 5, 10, 20, 30 and 40. Evaporator temperatures were kept around $10^{\circ} \mathrm{C}$ and FR at 0.8 . Fill liquids were R22, ethanol and distilled water. They concluded that the best inclination angles were between $40-70^{\circ}$ depending on aspect ratio. The authors mentioned that the aspect ratio had more effect on the performance of a thermosyphon compared to type of fill liquid and inclination. Payaruk et. al. (2000) correlated the heat transfer characteristics of an inclined closed two-phase thermosyphon at normal operating conditions. They used pipes of 7.5,

\footnotetext{
*Corresponding author. Email: skong@utar.edu.my
} 
11.1 and $25.4 \mathrm{~mm}$ ID with R22, R123, R134a, ethanol and water. They also used FRs at 0.50, 0.80 and 1.00 and ARs of 5, 10, 20, 30 and 40. Inclination angles were between $10-90^{\circ}$ with incremental steps of $10^{\circ}$. The controlled adiabatic wall temperature ranged from $0-30^{\circ} \mathrm{C}$. From their work they concluded that FR has no effect at $90^{\circ}$ but instead the fill liquid type affected the heat transfer characteristics. Khandekar et. al. (2003) investigated the operational regimes of a heat pipe using a 2 mm ID copper heat pipe with R123, water and ethanol and inclination angles set between $0-90^{\circ}$. The evaporator temperature range achieved was $100^{\circ} \mathrm{C}$ at $47 \mathrm{~W}$ with water and $22 \mathrm{~W}$ with ethanol. The optimal FR was found to be between 0.25-0.65 depending on fill liquid type.

Noie (2005) investigated the heat transfer characteristics of water filled two-phase closed thermosyphons with $25 \mathrm{I} / \mathrm{D} \times 32 \mathrm{~mm}$ OD copper pipes. Each thermosyphon was $980 \mathrm{~mm}$ long with a $51 \mathrm{~mm}$ O/D x $380 \mathrm{~mm}$ long water cooled jacket. Electrical resistance heating was applied with input power varying from 100-900 W. Evaporator wall temperature ranged from $100-180^{\circ} \mathrm{C}$. By varying the evaporator and adiabatic lengths, ARs of 7.45, 9.80 and 11.80 were obtained. Only the evaporator section was insulated with $55 \mathrm{~mm}$ thick rock wool. FRs were kept at $0.30,0.60$ and 0.90 . The results showed that evaporator wall temperature distribution was almost isothermal especially at the low power input. Also, for each thermosyphon, the maximum evaporator wall temperature attained depended upon a combination of $\mathrm{FR}$ and $\mathrm{AR}$, viz., $\mathrm{AR}=7.45$ with $\mathrm{FR}=0.90$ and $\mathrm{AR}=11.8$ with $\mathrm{FR}=$ 0.60. The author compared his heat transfer coefficients for $A R=9.8$ and at the various FRs and concluded that they were in reasonable agreement with the empirical correlations by Rohsenow (1962) and Imura et. al. (1977).

Ong et. al. (2014) investigated the axial temperature distribution and performance of R410a and water filled thermosyphons with various fill ratios $(0.25,0.40,0.66$ and 0.93$)$ and inclinations $(30,50,70$ and $90^{\circ}$ ) using a $38 \mathrm{~mm}$ OD x $807 \mathrm{~mm}$ long copper heat pipe. They varied the heat input from 100-830 W which generated evaporator wall temperature of up to $65^{\circ} \mathrm{C}$. They found that the performance increased as FR and inclination reduced. They also concluded that the R410a filled thermosyphon performed better at all inclinations and fill ratios at the temperature range of $30-65^{\circ} \mathrm{C}$. Guo and Nutter (2009) examined the effect of axial conduction along a heat pipe wall by separating the evaporator section of a thermosyphon from the condenser section with a non-conducting adiabatic piece. From their experiments they noted that axial conduction along a continuous thermosyphon wall causes nonuniform wall temperatures along the evaporator section up to $\pm 5^{\circ} \mathrm{C}$. Once the evaporator and condenser sections were separated by a nonconductive wall material, the evaporator section exhibited a more uniform temperature distribution to within $\pm 2{ }^{\circ} \mathrm{C}$. Previous investigations by Ong and Haider (2003) on low temperature R134a filled thermosyphons showed that a minimum of $3^{\circ} \mathrm{C}$ was required in order for the thermosyphon to operate.

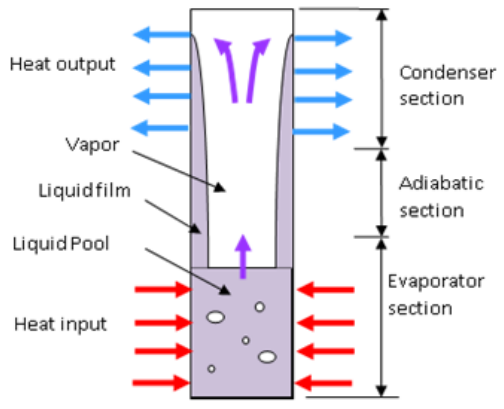

Fig. 1 Cross sectional view of a thermosyphon.

\section{OBJECTIVE OF INVESTIGATION.}

There are many other studies conducted on the performance of thermosyphons. However, they are mostly at low power inputs or low evaporator wall temperatures. Not much work has been performed on the performance of thermosyphons at temperatures greater than $100^{\circ} \mathrm{C}$. This study is essential for cooling processes that operate at temperatures exceeding $150^{\circ} \mathrm{C}$ such as in the foundry industry. Generally the molds and dies are cooled using water. The heated water is then cooled in the cooling tower. The objective of this paper is to investigate the performance of various water filled thermosyphons at temperatures between $30-150^{\circ} \mathrm{C}$ and to determine the effect at various power inputs, FRs, inclinations and ARs.

\section{METHODOLOGY.}

The experimental set up is shown in Fig. 2. Three thermosyphons were fabricated from $305 \mathrm{~mm}$ long copper tubes with different diameters as shown in Table 1. Aspect ratios (ARs), defined as the ratio of evaporator length $\left(\mathrm{L}_{\mathrm{e}}\right)$ /evaporator inner diameter $\left(\mathrm{D}_{\mathrm{i}}\right)$ equal to $10.0,6.7$ and 5.0 are obtained for the three units. The thermosyphons were filled with distilled water and insulated all round with $100 \mathrm{~mm}$ thick rockwool insulation. Fill ratio (FR) is defined as the ratio of liquid/evaporator internal volume. Fill ratios were kept at $0.25,0.50$, 0.75 and 1.00. Cooling was effected by a $50 \mathrm{~mm} \mathrm{O} / \mathrm{D}$ x $34 \mathrm{~mm} \mathrm{I} / \mathrm{D}$ x $127 \mathrm{~mm}$ long concentric water cooling jacket surrounding the condenser section. Coolant water was circulated by a $20 \mathrm{~W}$ submersible water pump. Coolant inlet temperature varied between $24-30^{\circ} \mathrm{C}$ and flowrate kept to between $0.003-0.05 \mathrm{~kg} / \mathrm{s}( \pm 0.001 \mathrm{~kg} / \mathrm{s})$. Heating was provided by nichrome wire wound round the evaporator section. Power (P) was regulated using an AC-transformer and varied from 5-405 W ( \pm $3.5 \%)$. Type $\mathrm{T}$ copper-constantan thermocouples $\left( \pm 0.5^{\circ} \mathrm{C}\right)$ were employed to measure the temperatures at the locations shown in Fig. 3. These were mechanically attached to the respective evaporator $\left(\mathrm{T}_{\mathrm{e} 1}-\right.$ $\left.\mathrm{T}_{\mathrm{e} 4}\right)$ and adiabatic $\left(\mathrm{T}_{\mathrm{ad} 1}, \mathrm{~T}_{\mathrm{ad} 2}\right)$ wall sections. End-of-condenser pipe wall $\left(\mathrm{T}_{\mathrm{p}}\right)$, saturation $\left(\mathrm{T}_{\mathrm{sat}}\right)$, coolant inlet $\left(\mathrm{T}_{\mathrm{wi}}\right)$ and outlet $\left(\mathrm{T}_{\mathrm{wo}}\right)$, ambient $\left(\mathrm{T}_{\mathrm{a}}\right)$ and insulation external surface $\left(\mathrm{T}_{\text {ins1 }}, \mathrm{T}_{\text {ins } 2}\right)$ temperatures were all data logged at 1 min intervals. Saturation pressure $\left(\mathrm{P}_{\text {sat }}\right)$ was noted before and after each experiment. Tests were carried out at various inclinations of $23^{\circ}, 45^{\circ}, 68^{\circ}$ and $90^{\circ}$ to the horizontal. Each series was repeated 3 times in order to ensure repeatability. The experimental results were found to be repeatable to within $\pm 3{ }^{\circ} \mathrm{C}$. The summary of experimental runs performed is tabulated in Table 2 .

Heat supplied at the evaporator section $\left(\dot{q}_{e}\right)$ is assumed equal to the heat removed by the cooling water $\left(\dot{q}_{w}\right)$, viz.,

$P=\dot{q}_{c}=\dot{q}_{w}=\dot{m}_{w} C_{p w}\left(T_{w o}-T_{w i}\right)$

The condenser wall surface temperature is calculated from

$T_{c}=\frac{T_{p}+T_{a d 1}}{2}$

The evaporator wall surface temperature can be obtained from the bulk temperature defined as

$T_{e, b}=\frac{\int_{0}^{x=L_{e}} T_{e} d x}{L_{e}}$

or from a simple arithmetic mean

$T_{e, m}=\frac{T_{e 1}+T_{e 2}+T_{e 3}+T_{e 4}}{4}$

The corresponding operating temperature differences between evaporator and condenser sections are then given by either the bulk temperature difference

$\Delta T_{b}=T_{e, b}-T_{c}$

or from the mean temperature difference 


$$
\Delta T_{m}=T_{e, m}-T_{c}
$$

The coolant water temperature is calculated from the average inlet and outlet water temperatures as

$T_{w}=\frac{T_{w o}+T_{w i}}{2}$

The evaporator heat transfer coefficient is calculated from

$h_{\text {evap }}=\left(A_{e}\left[\frac{\left(T_{e}-T_{\text {sat }}\right)}{P}-\frac{\ln \left(d_{o} / d_{i}\right)}{2 \pi k_{\text {wall }} L_{e}}\right]\right)^{-1}$

and the condenser heat transfer coefficient is calculated from

$h_{\text {cond }}=\left(A_{e}\left[\frac{\left(T_{s a t}-T_{c}\right)}{P}-\frac{\ln \left(d_{o} / d_{i}\right)}{2 \pi k_{\text {wall }} L_{c}}\right]\right)^{-1}$

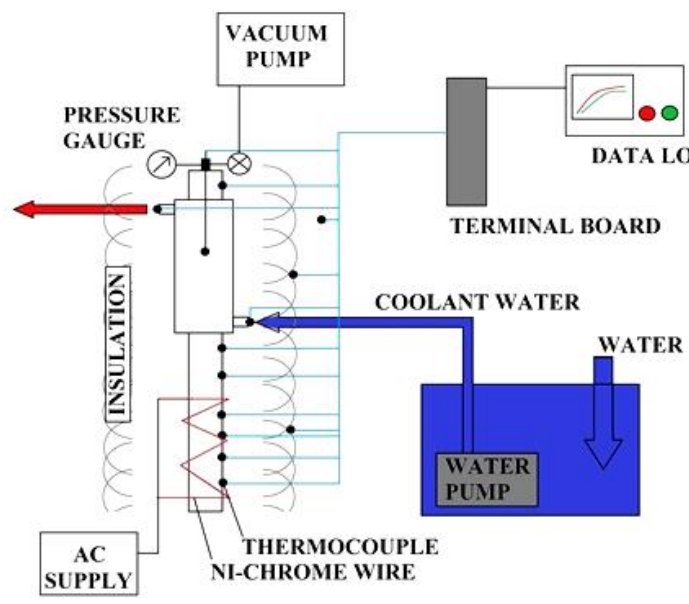

Fig. 2 Schematic of experimental set up

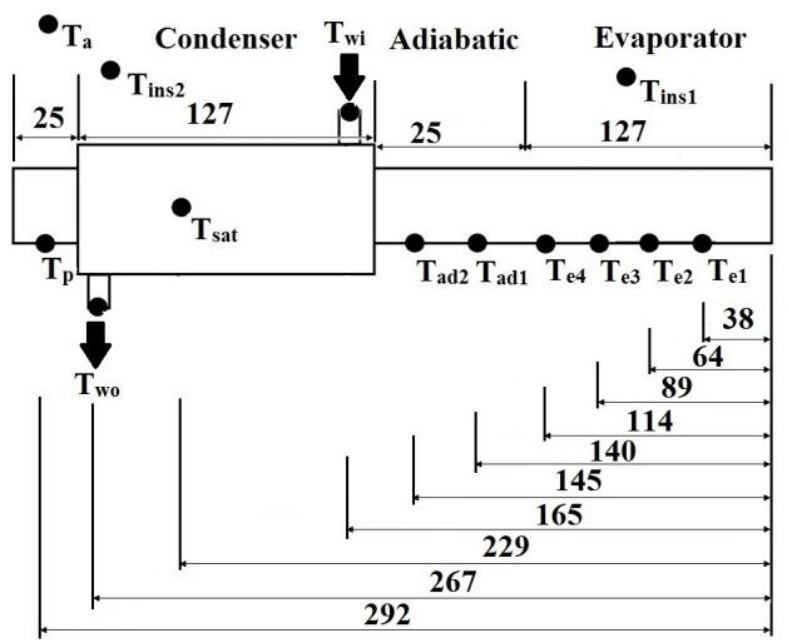

Fig. 3 Location of thermocouples in thermosyphon

Table 1. Dimensions of thermosyphons

\begin{tabular}{|c|c|c|c|c|c|c|c|}
\hline $\begin{array}{c}\mathbf{H P} \\
\#\end{array}$ & $\begin{array}{c}\mathbf{D}_{\mathbf{0}} \\
(\mathbf{m m})\end{array}$ & $\begin{array}{c}\mathbf{D}_{\mathbf{i}} \\
(\mathbf{m m})\end{array}$ & $\begin{array}{c}\mathbf{L}_{\mathbf{e}} \\
(\mathbf{m m})\end{array}$ & $\begin{array}{c}\mathbf{L}_{\mathbf{a d}} \\
(\mathbf{m m})\end{array}$ & $\begin{array}{c}\mathbf{L}_{\mathbf{c}} \\
(\mathbf{m m})\end{array}$ & $\mathbf{A R}$ & $\begin{array}{c}\mathbf{P} / \mathbf{A}_{\mathrm{e}} \\
\left(\mathbf{k W} / \mathbf{m}^{2}\right)\end{array}$ \\
\hline 1 & 15.8 & 12.7 & 127 & 25.4 & 127 & 10 & $10-30$ \\
\hline 2 & 22.2 & 19.1 & 127 & 25.4 & 127 & 6.7 & $5-48$ \\
\hline 3 & 28.6 & 25.4 & 127 & 25.4 & 127 & 5 & $4-24$ \\
\hline
\end{tabular}

Table 2. Summary of experimental runs performed

\begin{tabular}{|c|c|c|c|c|c|}
\hline Series & $\begin{array}{c}\text { HP } \\
\#\end{array}$ & Power $(\mathbf{W})$ & $\begin{array}{c}\dot{m}_{w} \\
(\mathbf{k g} / \mathbf{s})\end{array}$ & $\boldsymbol{\theta}\left({ }^{\circ}\right)$ & FR \\
\hline 1 & 2 & $5,18,38,70,113,210,360$ & 0.003 & 90 & 1.0 \\
\hline 2 & 2 & $5,18,38,70,113,210,360$ & 0.019 & 90 & 1.0 \\
\hline 3 & 2 & $5,18,38,70,113,210,360$ & 0.05 & 90 & 1.0 \\
\hline 4 & 2 & $18,38,70,113,210,360$ & 0.05 & 90 & $1.0,0.75,0.5,0.25$ \\
\hline 5 & 2 & $18,38,70,113,210,360$ & 0.05 & 68 & $1.0,0.75,0.5,0.25$ \\
\hline 6 & 2 & $18,38,70,113,210,360$ & 0.05 & 45 & $1.0,0.75,0.5,0.25$ \\
\hline 7 & 2 & $18,38,70,113,210,360$ & 0.05 & 23 & $1.0,0.75,0.5,0.25$ \\
\hline 8 & 2 & $18,38,70,113,210,360$ & 0.05 & $90,68,45,23$ & 1.0 \\
\hline 9 & 2 & $18,38,70,113,210,360$ & 0.05 & $90,68,45,23$ & 0.75 \\
\hline 10 & 2 & $18,38,70,113,210,360$ & 0.05 & $90,68,45,23$ & 0.5 \\
\hline 11 & 2 & $18,38,70,113,210,360$ & 0.05 & $90,68,45,23$ & 0.25 \\
\hline 12 & 1 & $50,100,150$ & 0.05 & 90 & 1.0 \\
\hline 13 & 2 & $38,70,113,210,360$ & 0.05 & 90 & 1.0 \\
\hline 14 & 3 & $50,90,130,250$ & 0.05 & 90 & 1.0 \\
\hline
\end{tabular}

\section{EXPERIMENTAL RESULTS.}

\subsection{Effect of condenser cooling rate.}

Condenser cooling water inlet temperature was not controlled. It varied between $27-30^{\circ} \mathrm{C}\left( \pm 1^{\circ} \mathrm{C}\right)$. Experiments were performed to determine the effect of condenser cooling rate with various water circulation rates of $0.003,0.019$ and $0.05 \mathrm{~kg} / \mathrm{s}$. The axial temperature distribution results for Series 1-3 are plotted in Fig. 4 for the low power input of $5 \mathrm{~W}$ and high power of $360 \mathrm{~W}$. The results show the temperature distribution increases with power and with decreasing mass flowrates. High power input raises the thermosyphon temperature throughout. Low coolant flow rates result in less cooling due to higher condenser temperatures. The Reynolds number for the coolant water flow ranged from 28-1400 indicating that the flow regime is laminar in the concentric tube water jacket. With the short section, it is also expected to be in the developing flow region. The difference between coolant water inlet and outlet temperature varied from $27^{\circ} \mathrm{C}$ at high power and low flowrate to about $0.5^{\circ} \mathrm{C}$ at low power and high flowrate. For subsequent series, high flow rate at $0.05 \mathrm{~kg} / \mathrm{s}$ was employed in order to have a more uniform condenser section temperature. However, at this high flow rate, it would not be possible to evaluate the heat transfer at the condenser section accurately. Hence heat transfer at the evaporator section of the thermosyphon was assumed equal to the electrical power input.

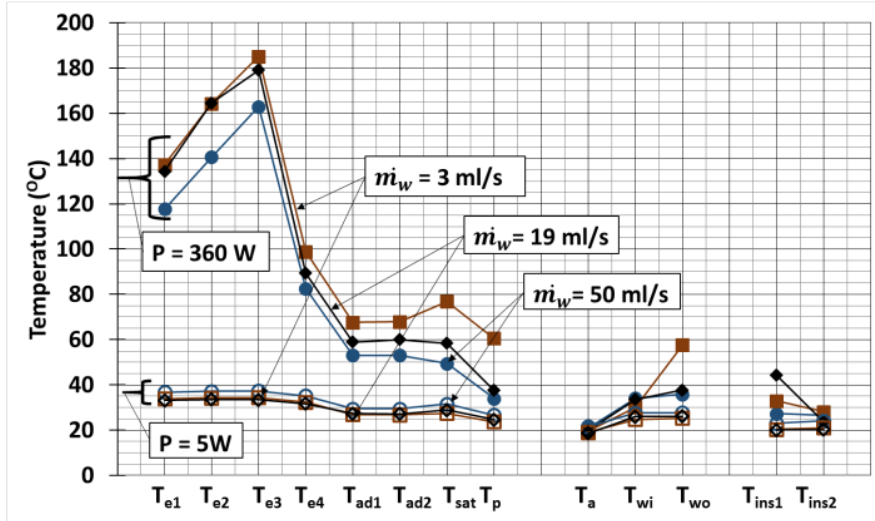

Fig. 4 Effect of coolant mass flow rate (Series 1, 2 and 3)

\subsection{Effect of power input on axial temperature distribution.}

Typical axial temperature distribution for various power inputs at the high water coolant flow rate of $0.05 \mathrm{~kg} / \mathrm{s}$ (Series 3) are shown in Fig. 5. The results generally show that the thermosyphon wall temperature distribution increased with power input. This is to be expected as higher heat input at the evaporator section would result in a higher 
thermosyphon operating temperature. The increase in evaporator wall temperature is higher than in the adiabatic or condenser sections. The results also show that at low input power, evaporator wall temperature is quite uniform. At power input beyond $18 \mathrm{~W}$ the distribution tended to be non-uniform. It could be seen that evaporator wall temperature reached a maximum of $35^{\circ} \mathrm{C}$ at $5 \mathrm{~W}$ and $185^{\circ} \mathrm{C}$ at $360 \mathrm{~W}$. Adiabatic wall temperature was nearly uniform, around $27^{\circ} \mathrm{C}$ at $5 \mathrm{~W}$ and $68^{\circ} \mathrm{C}$ at $360 \mathrm{~W}$. The temperature at the top end of the condenser section exhibited temperatures slightly higher than that at the adiabatic section. Coolant water increased by about $0.5^{\circ} \mathrm{C}$. Mean coolant temperature was lower than adiabatic or condenser top end temperatures.

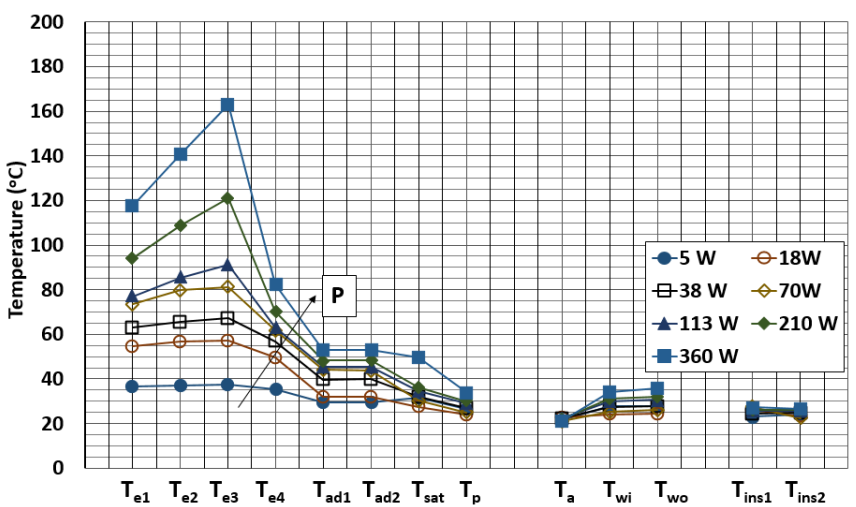

Fig. 5 Typical axial temperature distribution (Series 3)

\subsection{Bulk and mean wall temperatures.}

The average evaporator wall temperature could be obtained from the bulk wall temperature $\left(T_{b}\right)$ or from the mean wall temperature $\left(T_{e, m}\right)$ as calculated from Eqns. (3) and (4), respectively. The results indicate that calculated bulk wall temperature could reach about $16^{\circ} \mathrm{C}$ higher than the calculated mean value at the high power of $360 \mathrm{~W}$ and by $0.3^{\circ} \mathrm{C}$ at the low power of $5 \mathrm{~W}$ due to the non-uniformity in axial temperature distribution. Using these calculated average values, the corresponding operating temperature differences based upon bulk and mean evaporator wall temperatures calculated from Eqns. (5) and (6) are utilized in Fig. 6 which shows a set of typical results of power vs the two defined operating temperature differences for Series 1 . The results show that power varied linearly with either $\Delta \mathrm{T}_{\mathrm{m}}$ or $\Delta \mathrm{T}_{\mathrm{b}}$ with regression coefficients greater than 0.99 at the input power above $18 \mathrm{~W}$. Although both sets of results exhibited linear relationship, the difference between $\Delta \mathrm{T}_{\mathrm{b}}$ and $\Delta \mathrm{T}_{\mathrm{m}}$ obtained at $360 \mathrm{~W}$ is about $14^{\circ} \mathrm{C}$ while at the low power below $18 \mathrm{~W}$, the difference is negligible and a different set of linear relationship was observed. For simplicity, most investigators utilised the mean evaporator temperature, $\mathrm{T}_{\mathrm{m}}$.

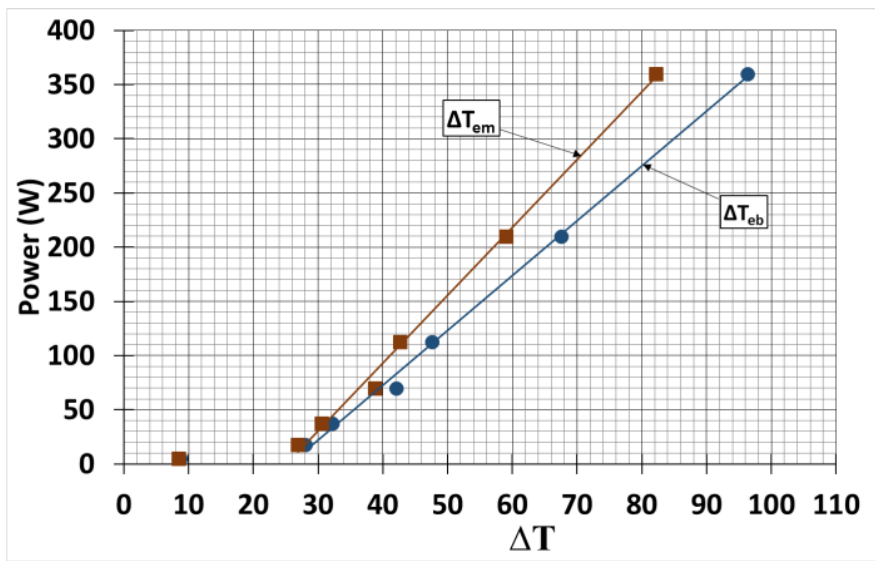

Fig. 6 Typical comparison of Power input vs mean and bulk temperature difference (Series 1)
The performance of a thermosyphon could be gauged from the overall resistance $\left(\mathrm{R}_{\mathrm{o}}\right)$ defined by

$$
R_{O}=\frac{\Delta T}{P}
$$

Here, different values of $R_{0}$ could be obtained, depending upon the definition of $\Delta$ T. From Fig. 6 , the reciprocal of the gradients of the $\mathrm{P}$ vs $\Delta \mathrm{T}_{\mathrm{m}}$ or $\Delta \mathrm{T}_{\mathrm{b}}$ curves would give the value of $\mathrm{R}_{\mathrm{o}}$. Here, we obtain values of $R_{o}$ from 0.23 with $\Delta T_{m}$ and 0.27 with $\Delta T_{b}$. This difference is quite substantial considering that the thermocouple are capable of measuring temperature differences to within $\pm 1^{\circ} \mathrm{C}$ and the actual temperature difference between evaporator and condenser ranged from $30-90^{\circ} \mathrm{C}$. However, for simplicity, the mean temperature relationship is employed from here on when comparing the performances of the thermosyphons as is done by other investigators.

\subsection{Effect of fill ratio.}

The effect of FR at various inclinations $\left(90^{\circ}, 67^{\circ}, 45^{\circ}\right.$ and $\left.22.5^{\circ}\right)$ for Series 4-7 are shown in Figs. 7-10, respectively. The results show that generally, input power $(\mathrm{P})$ or heat transfer from the thermosyphon varies linearly with mean operating temperature difference $\left(\Delta \mathrm{T}_{\mathrm{m}}\right)$. Two distinct operating regions are observed, viz., low power region 0-40 W and high power region above $40 \mathrm{~W}$. The different operating regions were attributed to the effect of pure axial heat conduction directly along the thermosyphon wall from the evaporator to the condenser section. This conduction effect is greater at the lower heat input. At the high power input, the performance is very nearly linear with regression coefficients greater than 0.99 . The present investigation focuses on high operating power or high evaporator wall temperature. At this high power, the results of Fig. 7 show that at $90^{\circ}$ inclination, the thermosyphon with FR $=1.00$ out-performed the others. The results of Figs. 8-10 show that at low inclinations, the lesser filled thermosyphons performed better.

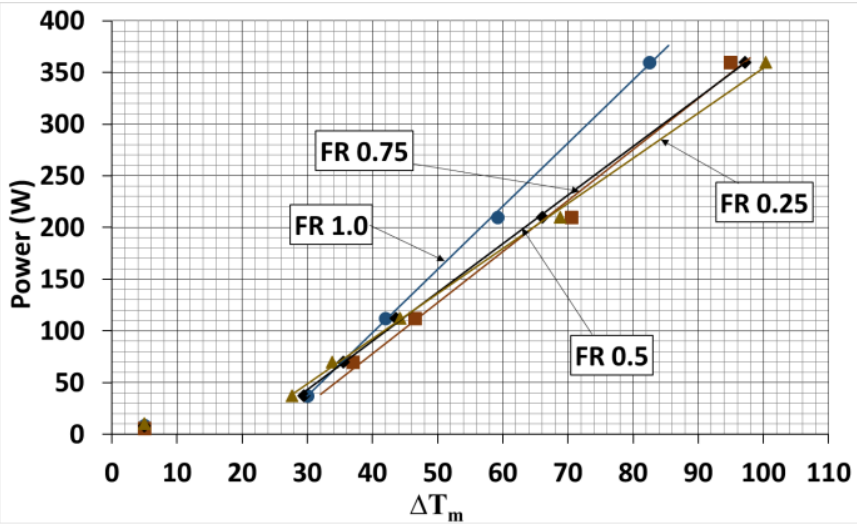

Fig. 7 Effect of fill ratio at $90^{\circ}$ (Series 4)

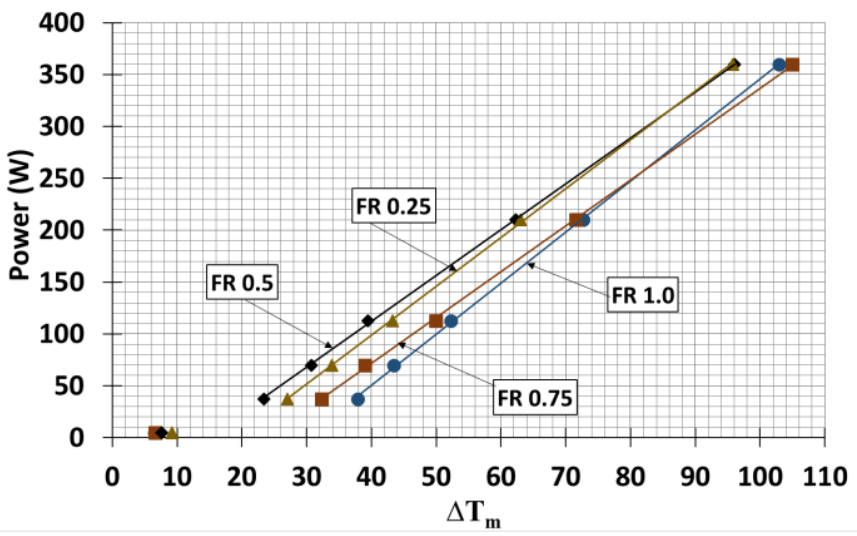

Fig. 8 Effect of fill ratio at $68^{\circ}$ (Series 5) 


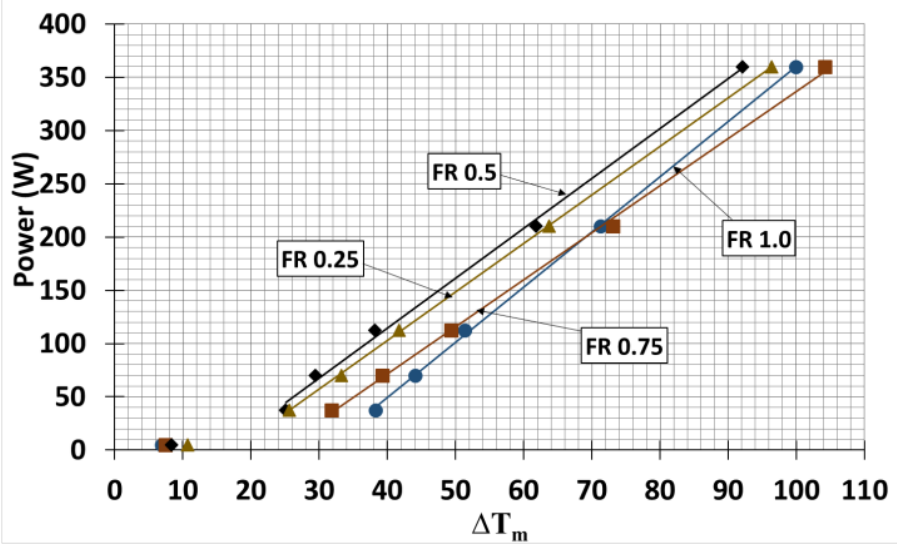

Fig. 9 Effect of fill ratio at $45^{\circ}$ (Series 6)

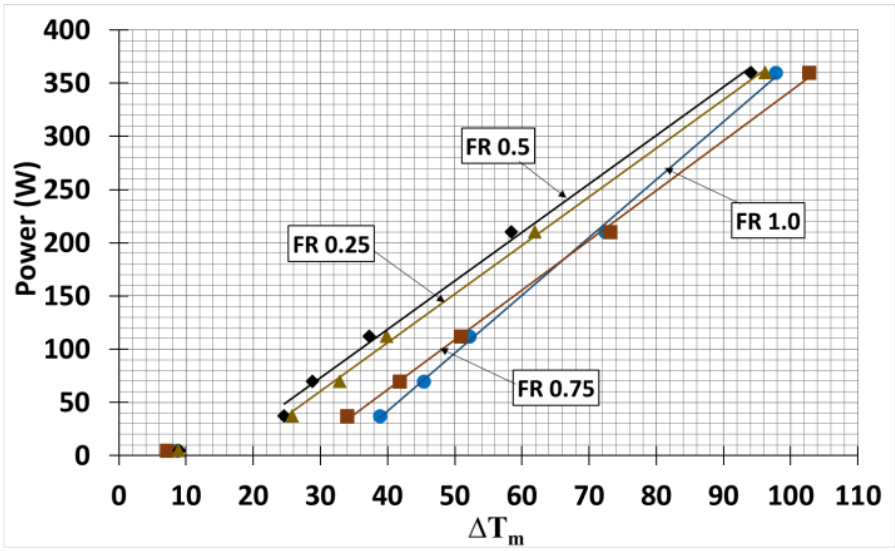

Fig. 10 Effect of fill ratio at $23^{\circ}$ (Series 7)

\subsection{Effect of inclination.}

The effect of inclination at various FRs $(1.00,0.75,0.5$ and 0.25$)$ for Series 8-11 are shown in Figs. 11-14. Again, the results show the two distinct operating ranges at around $40 \mathrm{~W}$. The results of Figs. 11 and 12 show that with FR $=1.00$ and 0.75 , the vertical thermosyphon outperformed the others. Figures 13 and 14 show that with $F R=0.50$ and 0.25 , the vertical thermosyphon did not perform as well as the others.

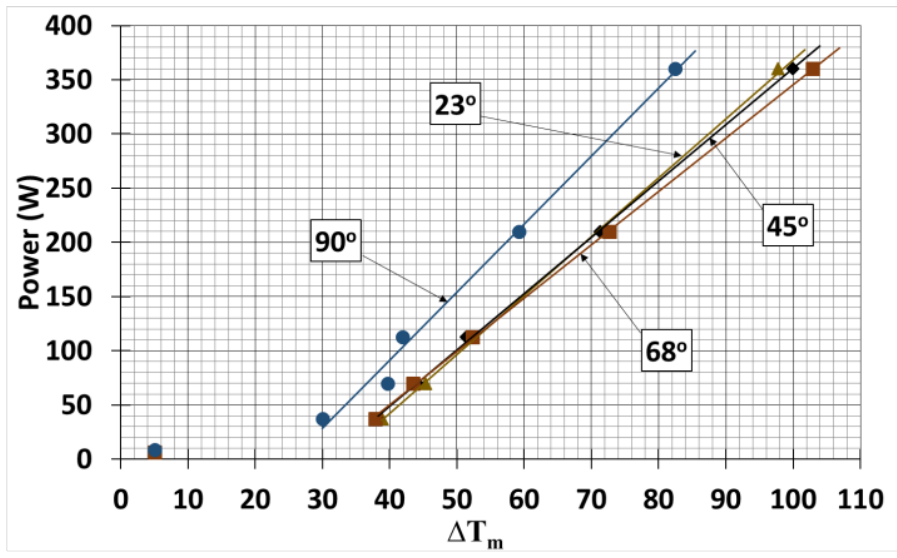

Fig. 11 Effect of inclination with FR $=1.0($ Series 8$)$

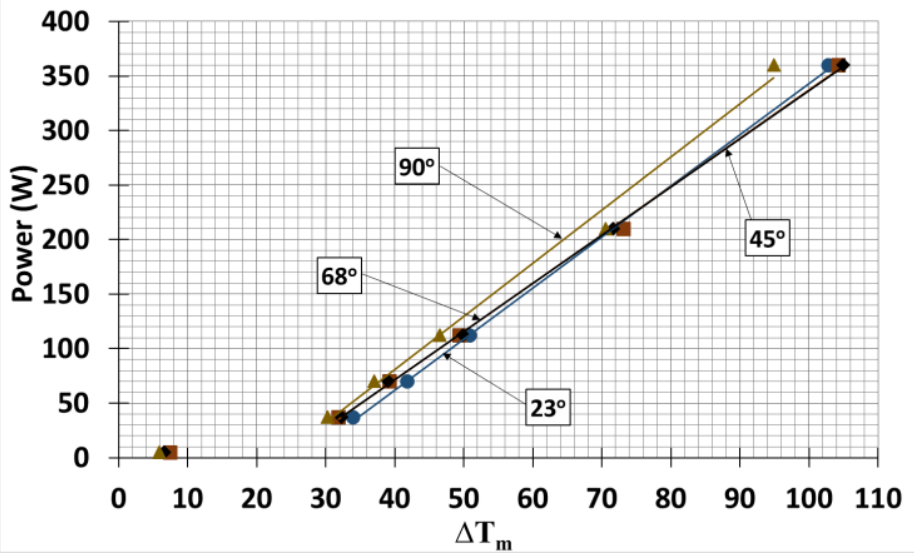

Fig. 12 Effect of inclination with $F R=0.75$ (Series 9)

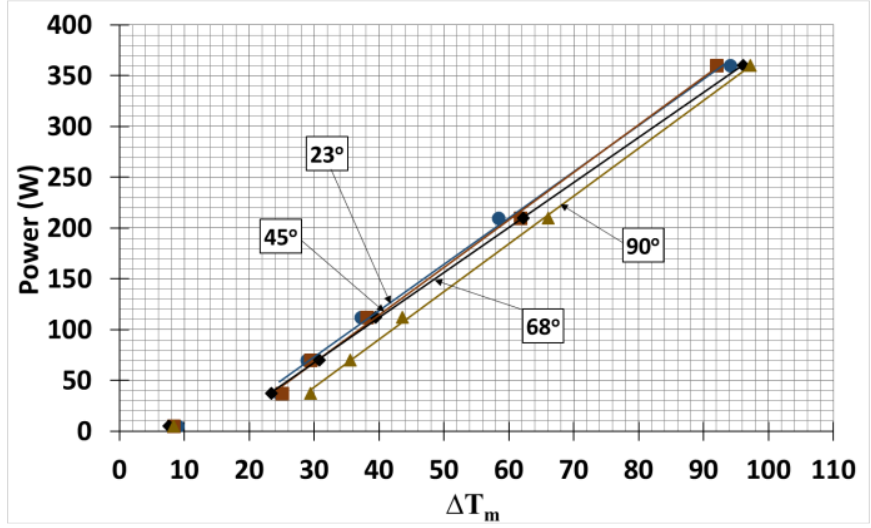

Fig. 13 Effect of inclination with $F R=0.5$ (Series 10)

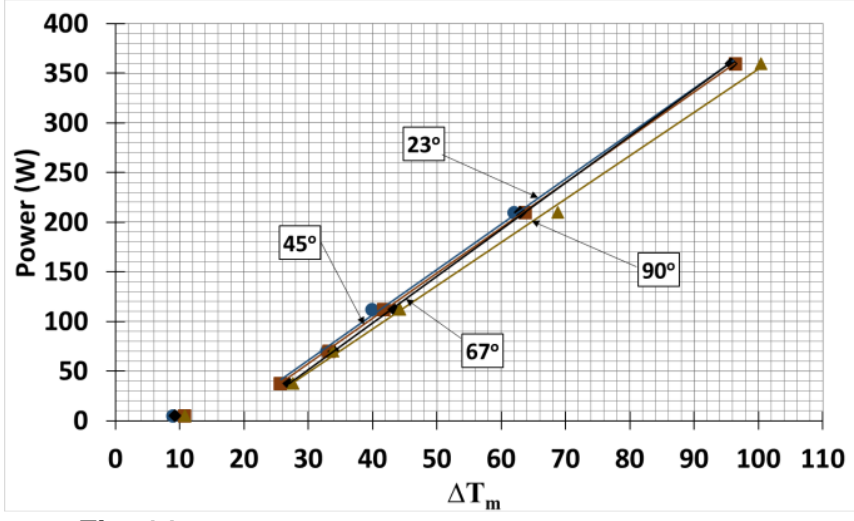

Fig. 14 Effect of inclination with $F R=0.25$ (Series 11)

\subsection{Effect of aspect ratio (AR).}

Three different thermosyphons with different ARs were tested. Since the thermosyphons had different dimensions, performance was based on evaporator input heat flux defined as input power/evaporator heating surface area. The AR effect is shown in Fig. 15 for Series 12-14. The results show that thermosyphon HP\#1 with $A R=10$ performed better than the other two units with ARs equal to 6.7 and 5. The dimensions of thermosyphons used by other researchers are summarized in Table. 3. A comparison of the results with the present ones in Fig. 15 shows that at a certain fixed temperature difference, the heat flux dissipated increased with increase of AR and overall thermal resistance decreased. 


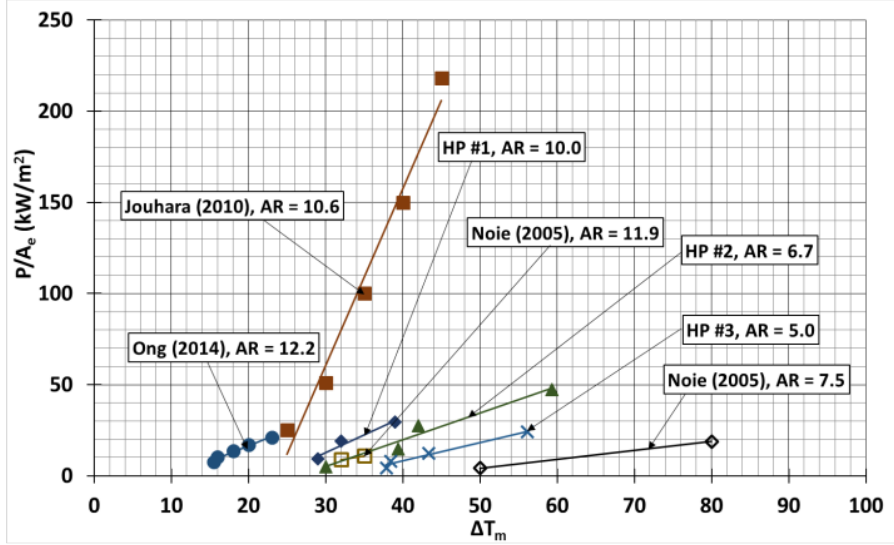

Fig. 15 Effect of aspect ratio (Series 12, 13 and 14)

Table 3. Summary of experimental parameters used by other researchers

\begin{tabular}{|c|c|c|c|c|c|c|c|c|c|}
\hline Author & $\begin{array}{c}\text { Input } \\
\text { power } \\
\text { (W) }\end{array}$ & $\begin{array}{c}\text { Evap. } \\
\text { wall } \\
\text { temp. } \\
\left({ }^{\circ} \mathrm{C}\right)\end{array}$ & $\begin{array}{c}\text { Cond. } \\
\text { wall } \\
\text { temp. } \\
\left({ }^{\circ} \mathrm{C}\right)\end{array}$ & $\begin{array}{c}\mathbf{L}_{\mathrm{e}} \\
(\mathbf{m m})\end{array}$ & $\begin{array}{c}\mathbf{L}_{\mathbf{c}} \\
(\mathbf{m m})\end{array}$ & $\begin{array}{c}\mathbf{D}_{0} \\
(\mathbf{m m})\end{array}$ & $\begin{array}{c}\mathbf{D}_{\mathbf{i}} \\
(\mathbf{m m})\end{array}$ & $\mathbf{A R}$ & $\begin{array}{c}\mathbf{P} / \mathbf{A}_{\mathbf{e}} \\
(\mathrm{kW} / \\
\left.\mathrm{m}^{2}\right)\end{array}$ \\
\hline \multirow{2}{*}{ Noie [7] } & \multirow{2}{*}{$\begin{array}{c}100- \\
900\end{array}$} & $120-130$ & $80-90$ & 377 & \multirow{2}{*}{380} & \multirow[t]{2}{*}{32} & \multirow[t]{2}{*}{25} & 11.8 & $\begin{array}{l}10- \\
11\end{array}$ \\
\hline & & $70-110$ & $30-40$ & 238 & & & & 7.45 & $5-20$ \\
\hline $\begin{array}{c}\text { Jouhara } \\
{[13]}\end{array}$ & $0-300$ & 50 & $30-90$ & 64 & 70 & 12 & 6 & 10.6 & $\begin{array}{l}25- \\
220\end{array}$ \\
\hline $\begin{array}{c}\text { Nazarul } \\
{[10]}\end{array}$ & $\begin{array}{l}100- \\
830\end{array}$ & $35-60$ & $35-40$ & 390 & 327 & 38 & 32 & 12.2 & $\begin{array}{l}10- \\
20\end{array}$ \\
\hline
\end{tabular}

\subsection{Evaporator and condenser heat transfer coefficients.}

Evaporator and condenser heat transfer coefficients calculated from Eqns. (8) and (9) are plotted vs Power in Figs. 16 and 17, respectively, for series 4 . The results show that typically evaporator and condenser heat transfer coefficients increase with input power.

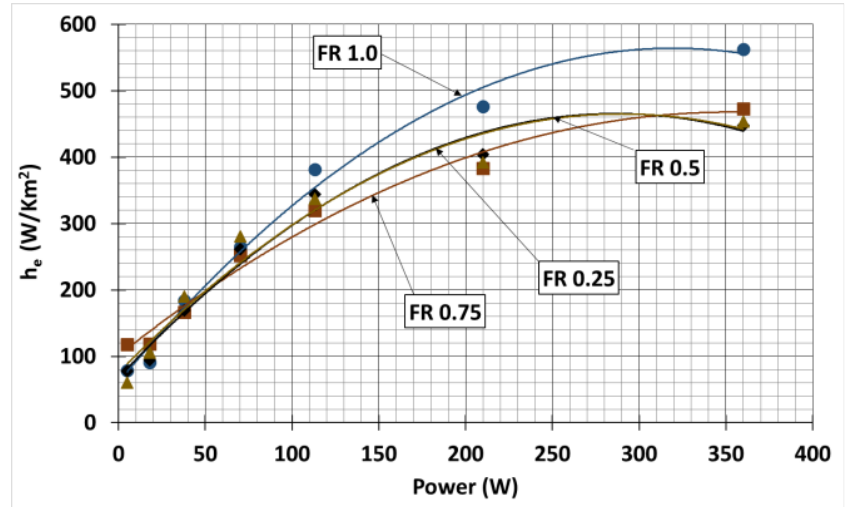

Fig. 16 Typical evaporator heat transfer coefficient (Series 4)

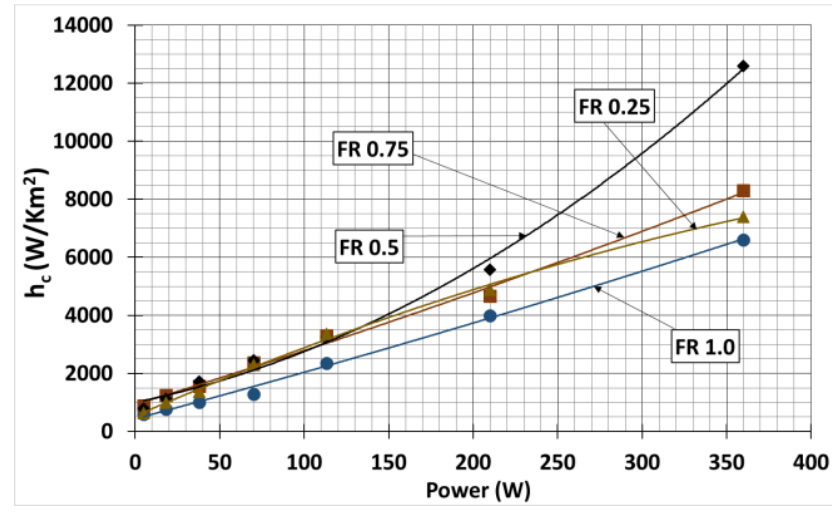

Fig. 17 Typical condenser heat transfer coefficient (Series 4)

\subsection{Thermal resistance.}

Typical overall thermal resistance results obtained for vertical pipe are compared with other researchers in Fig. 18. The results correlated well and could be represented by

$R_{O}=\frac{39.7}{P}$

with a regression coefficient of $\mathrm{R}^{2}=0.874$.

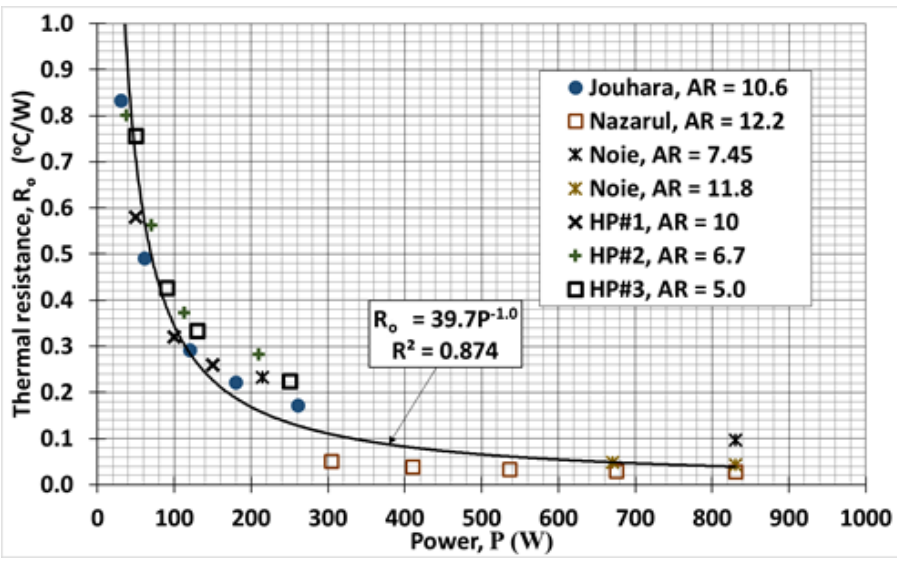

Fig. 18 Comparison of $R_{o}$

\section{Conclusions}

The thermal performance of three water-filled thermosyphons subjected to evaporator wall temperatures between $30-150^{\circ} \mathrm{C}$ were investigated. The effect of condenser cooling rates together with various fill ratios, pipe inclinations and aspect ratios were considered. The following conclusions could be drawn:

- High power input results in higher thermosyphon wall temperatures.

- $\quad$ High condenser cooling rate results in lower thermosyphon wall temperatures.

- $\quad$ Differences in evaporator wall temperatures based on bulk and mean definitions could be as much as $14^{\circ} \mathrm{C}$

- $\quad$ There are two distinct operating regions observed at around $40 \mathrm{~W}$.

- Axial temperature distribution was uniform at low power input $(<18 \mathrm{~W})$ and non-uniform at high power input $(>$ $18 \mathrm{~W})$.

- $\quad$ The best performing thermosyphon was found to be at a fill ratio of 1.0 and inclination at $90^{\circ}$ at low operating temperature difference.

- $\quad$ A high aspect ratio thermosyphon is preferred.

\section{NOMENCLATURE.}

$A_{c}$

$\mathrm{A}_{\mathrm{e}}$

AR

$\mathrm{C}_{\mathrm{pw}}$

$\mathrm{d}_{\mathrm{o}}$

$\mathrm{d}_{\mathrm{i}}$

$\mathrm{h}_{\text {cond }}$

$\mathrm{h}_{\text {evap }}$

$\mathrm{k}_{\text {wall }}$

$\mathrm{L}_{\mathrm{ad}}$

$\mathrm{L}_{\mathrm{c}}$

$\mathrm{L}_{\mathrm{e}}$ area of condenser section $\left(\mathrm{m}^{2}\right)$ area of evaporator section $\left(\mathrm{m}^{2}\right)$ aspect ratio of evaporator length to pipe diameter specific heat of water $(\mathrm{kJ} / \mathrm{kg} \mathrm{K})$ pipe outer diameter $(\mathrm{m})$ pipe inner diameter $(\mathrm{m})$ condensation heat transfer coefficient $\left(\mathrm{W} / \mathrm{m}^{2} \mathrm{~K}\right)$ evaporation heat transfer coefficient $\left(\mathrm{W} / \mathrm{m}^{2} \mathrm{~K}\right)$ thermal conductivity of pipe $(\mathrm{W} / \mathrm{mK})$ adiabatic length $(\mathrm{m})$ condenser length (m) evaporator length $(\mathrm{m})$ 


$\begin{array}{ll}\dot{m}_{w} & \text { mass flow rate of water }(\mathrm{kg} / \mathrm{s}) \\ \mathrm{P} & \text { power input }(\mathrm{W}) \\ \mathrm{R}_{\mathrm{o}} & \text { overall thermal resistance }(\mathrm{K} / \mathrm{W}) \\ \mathrm{T}_{\mathrm{a}} & \text { ambient temperature }\left({ }^{\circ} \mathrm{C}\right) \\ \mathrm{T}_{\mathrm{ad} 1, \mathrm{Tad} 2} & \text { adiabatic temperatures }\left({ }^{\circ} \mathrm{C}\right) \\ \mathrm{T}_{\mathrm{c}} & \text { condenser temperature }\left({ }^{\circ} \mathrm{C}\right) \\ \mathrm{T}_{\mathrm{e}, \mathrm{b}} & \text { evaporator wall bulk temperature }\left({ }^{\circ} \mathrm{C}\right) \\ \mathrm{T}_{\mathrm{e}, \mathrm{m}} & \text { evaporator mean temperature }\left({ }^{\circ} \mathrm{C}\right) \\ \mathrm{T}_{\mathrm{ins}} & \text { insulation surface temperatures }\left({ }^{\circ} \mathrm{C}\right) \\ \mathrm{T}_{\mathrm{p}} & \text { temperature at top of condenser }\left({ }^{\circ} \mathrm{C}\right) \\ \mathrm{T}_{\mathrm{sat}} & \text { saturation temperature }\left({ }^{\circ} \mathrm{C}\right) \\ \mathrm{T}_{\mathrm{wi}}, \mathrm{T}_{\mathrm{wo}} & \text { water inlet and outlet temperatures }\left({ }^{\circ} \mathrm{C}\right) \\ \Delta \mathrm{T}_{\mathrm{b}} & \text { bulk temperature difference }\left({ }^{\circ} \mathrm{C}\right) \\ \Delta \mathrm{T}_{\mathrm{m}} & \text { mean temperature difference }\left({ }^{\circ} \mathrm{C}\right) \\ \mathrm{P}_{\mathrm{sat}} & \text { saturation pressure }(\text { bar }) \\ \dot{q}_{c} & \text { condenser heat transfer rate }(\mathrm{kJ} / \mathrm{s}) \\ \dot{q}_{e} & \text { evaporator heat transfer rate }(\mathrm{kJ} / \mathrm{s}) \\ \dot{q}_{w} & \text { heat removed by coolant }(\mathrm{kJ} / \mathrm{s}) \\ \theta & \text { inclination }\left({ }^{\circ}\right)\end{array}$

\section{REFERENCES}

Guo, W., and Nutter, D. W., 2009, "An experimental study of axial conduction through a thermosyphon pipe wall," Applied Thermal Energy, 29, 3536-3541.

http://dx.doi.org/10.1016/j.applthermaleng.2009.06.008

Gurses, A. C. and Cannistraro, C., 1991, "The inclination effect on the performance off water-filled heat pipes," Renewable Energy, 1, 667674.

http://dx.doi.org/10.1016/0960-1481(91)90012-E

Imura, H., Kusada, K., Oyata, J., Sakamoto, N., 1977, "Heat transfer in two-phase closed-type thermosyphons," Trans. Japan Society of Mechanical Engineers, 22, 485-493.

Jouhara, H. and Robinson, A. J., 2010, "Experimental investigation of small diameter two-phase closed thermosyphons charged with water, FC-84, FC-77, and FC-3283," Applied Thermal Engineering, 30, 201211.

http://dx.doi.org/10.1016/i.applthermaleng.2009.08.007
Khandekar, S., Dollinger, N., and Groll, M., 2003, "Understading operational regimes of closed loop pulasating heat pipes: an experimental study," Applied Thermal Engineering, 23, 707-719. http://dx.doi.org/10.1016/S1359-4311(02)00237-5

Nguyen-Chi, H., and Groll, M., 1981, "Entrainment or flooding limit in a closed two-phase thermosyphon," Heat Recovery Systems, 1, 275. http://dx.doi.org/10.1016/0198-7593(81)90038-2

Noie, S., 2005, "Heat transfer characteristics of a two-phase closed thermosyphon," Applied Thermal Engineering, 25, 495-506. http://dx.doi.org/10.1016/j.applthermaleng.2004.06.019

Ong, K. S., and Haider-E-Alahi, M., 2003, "Performance of a R-134a filled thermosyphon," Applied Thermal Energy, 22, 2373-2381. http://dx.doi.org/10.1016/S1359-4311(03)00207-2

Ong, K. S., Tong, W. L., Gan, J. S., and Hisham, N., 2014, "Axial temperature distribution and performance of R410a and water filled thermosyphon at various fill ratios and inclinations," Frontiers of Heat Pipes, 5, 1-7. http://dx.doi.org/10.5098/fhp.5.2

Payaruk, T., Terdtoon, P., and Ritthidech, S., 2000, "Correlations to predict heat transfer characteristics of an inclined closed two-phase thermosyphon at normal operating conditions," Applied Thermal Engineering, 20, 781-90. http://dx.doi.org/10.1016/S1359-4311(99)00047-2

Peterson, G., 1994, An Introduction to Heat Pipes Modeling, Testing, and Applications, New York: Wiley Interscience.

Rohsenow, W. M., 1962, "A method of correlating heat transfer data for surface boiling curves", International Journal of Heat Transfer, ASME, 84, 969 .

Terdtoon, P., Ritthidej, S., and Shiraishi, M., 1996, "Effect of aspect ratio and bond number on heat transfer characteristics of an inclined two-phase closed thermosyphon at normal operating conditions," 5th International Symposium on Heat Pipes, Melbourne. 